\title{
Досвід застосування методики дзеркальної терапії в комплексній реабілітації постінсультних хворих з порушеннями функцій верхніх кінцівок
}

\author{
Костинська О. М., Чернишова I. М., Галенко М. О. \\ Український науково-дослідний інститут протезування, протезобудування та відновлення \\ працездатності, м. Харків, Україна
}

Актуальність дослідження. Більшість існуючих методів реабілітації постінсультних хворих дороговартісні, потребують тривалого перебування людини в реабілітаційних закладах і обмежено використовуються в домашніх умовах. Пошук та впровадження ефективних, доступних та безпечних методик реабілітації хворих 3 порушеннями функцій верхніх кінцівок є одним 3 актуальних завдань сьогодення. Одним із рішень може бути застосування в комплексній реабілітації методики дзеркальної терапії.

Мета дослідження: вивчення ефективності комбінованого застосування методики дзеркальної терапії в поєднанні $з$ сенсомоторними таблицями та навіюванням у комплексній реабілітації хворих 3 порушеннями функцій верхніх кінцівок внаслідок перенесеного інсульту.

Матеріали та методи. Під час проведення дзеркальної терапії для відновлення великої та дрібної моторики пацієнтів 3 наслідками інсульту у дзеркалі повинна повністю відображатися здорова кінцівка, а уражена кінцівка повинна бути повністю захована. Хворий здійснює вправи обома руками. Застосуються різні види захоплення кистю, напруження різних груп м'язів верхніх кінцівок із застосуванням формул навіювання, а також виконання вправ перед дзеркалом на спеціально розроблених сенсомоторних таблицях.

Результати та їх обговорення. В клініці УкрНДІ протезування методика дзеркальної терапії в поєднанні з навіюванням та сенсомоторними таблицями застосовується 3 листопада 2015 року. На сьогодні проведено понад 800 сеансів дзеркальної терапії у 54 осіб. У $55,5 \%$ хворих за даними тестування ("Box and Blocs”) спостерігалось збільшення кількості виконаних дій в середньому на $22 \%$. Решта хворих збільшила результати тестування приблизно на $10 \%$.

Висновки. Перевагою методики дзеркальної терапії є її ефективність, простота, безпечність та доступність, можливість самостійного використання пацієнтом. Дана методика відповідає основним засадам рухової реабілітації - висока інтенсивність та повторюваність ціль-орієнтованих завдань у поєднанні зі зворотним зв'язком.

Перспективи подальших досліджень. Дослідження біологічного зворотного зв'язку дозволить покращити ефективність реабілітації постінсультних хворих.

Ключові слова: дзеркальна терапія, біологічно-зворотний зв'язок, постінсультні хворі, сенсомоторні таблиці. 